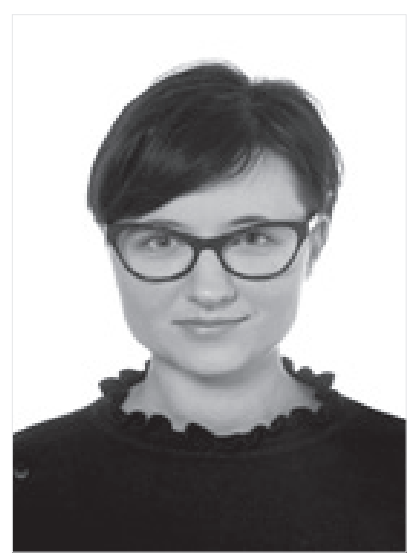

Kotryna Rekašiūtè - jungtinès Lietuvių literatūros ir tautosakos instituto ir Vilniaus universiteto filologijos mokslo krypties doktorantè.

Moksliniai interesai: Mažosios Lietuvos istorija ir literatūra.

El.paštas: kotryna.re@gmail.com

Kotryna Rekašiūtè: PhD student in Humanities, The University of Vilnius and The Institute of Lithuanian Literature and Folklore.

Research interests: history and literature of Lithuania Minor. E-mail: kotryna.re@gmail.com

\title{
Kotryna Rekašiūtè
}

\section{Lietuviu literatūros ir tautosakos institutas, Vilniaus universitetas}

\section{KAI KURIE MARTYNO LIUDVIKO RËZOS MASONIŠKŲ RYŠIŲ ASPEKTAI IR LIT UANISTINE் VEIKLA ${ }^{1}$}

\begin{abstract}
Anotacija
Martynas Liudvikas Rèza (Martin Ludwig Rhesa, 1776-1841) - ne tik vienas žymiausių lituanistų lietuvių istorijoje, bet ir garsus Karaliaučiaus masonų ložès Po trimis karūnomis narys, stebinęs ir vis dar tebestebinantis savo interesu platumu bei atliktų darbų gausa. Rèzos veiklos, jo literatūrinių užmojų spektras platus - nuo religinių raštų rengimo iki pasaulietinių grožinių kūrinių ir folkloristikos publikavimo. Atidžiau gilinantis ị profesoriaus lituanistinę veiklą, svarbus yra Rėzos masoniškumo aspektas. Masoniškų atgarsių aptinkama Rèzos leidybinèje veikloje, korespondencijoje ir ryšiuose su žinomais mokslininkais bei literatais. Straipsnyje siekiama atidžiau pažvelgti ị masoniškuosius Rėzos ryšius jo lituanistinejje veikloje.
\end{abstract}

PAGRINDINIAI ŽODŽIAI: Rèza, masonai, laisvieji mūrininkai, ryšiai, sklaida, lietuvių raštija.

\footnotetext{
Abstract

Martynas Liudvikas Rèza (Martin Ludwig Rhesa, 1776-1841) is not only one of the most famous Lithuanian in the history of Lithuanians writings, but also a famous member of the

1 Straipsnis parašytas mokslinès stažuotès Greifswalde (Vokietija) metu. Dèkoju Ernsto Moritzo Arndto universiteto (Ernst-Moritz-Arndt-Universität Greifswald) Baltistikos institutui už sudarytas sąlygas stažuotis.
} 
Kotryna Rekašiūtè

Kai kurie Martyno Liudviko Rėzos

masoniškų ryšiu aspektai ir lituanistinė veikla

Königsberg Masonic lodge $\mathrm{Zu}$ den drei Krönen, who has been astonished by the amplitude of his interests and the abundance of his works that still surprising. The range of activities of Rèza, his literary ambition range are wide - from the religious writings to the publishing of secular literature and folklore. Carefully going into the professors' Lithuanian activities, the aspect of Rèza's Masonry is important. Masonic echoes are found in Rèza's publishing activities, correspondence and in relationships with well-known scholars and writers. The article aims to look more closely at the Masonic relations of Rėza in his Lithuanian activities.

KEY WORDS: Rėza, masonry, freemasons, relationships, dispersions, Lithuanian Writings.

doi:http://dx.doi.org/10.15181/rh.v24i0.1910

Itvadas

XVIII-XIX a. nušvietusios Švietimo epochos (vok. Aufklärung) idèjos, siekusios išugdyti naują, dorą, geresnị žmogų, deklaravusios proto, filosofijos, išminties, mokslo svarbą, kèlusios svarbius socialinius klausimus (Gysi 1958, 15), siekusios kultūroje įtvirtinti liaudies kalbą ir pripažinusios tautosakos meninę vertę, esmingai paveikè Rèzą ir buvo vaisingai realizuotos jo lituanistinėje veikloje. Aptariamąją epochą, pritraukusią mąstytojų, filosofų, rašytojų dèmesį, reikètų laikyti draugijų amžiumi (Hof 1996, 91) ir filosofijos šimtmečiu (Schneiders 1997, 7). Viena iš draugiju - masonai (vok. Freimaurerei), arba laisvieji mūrininkai. Tai pusiau slapta, priesaika susietų, pavyzdingo elgesio vyrų organizacija, iškilusi kaip Švietimo amžiaus padarinys ir tapusi viena populiariausių draugijų Europoje. Savo ideologija ir interesais draugija atitiko Švietimo epochos deklaruotas idèjas - asmeninio tobulejimo, išsimokslinimo, pažangaus proto, demokratijos, filantropijos, religinès tolerancijos, pabrěžè socialinio teisingumo svarbą visuomenèje (Dotzauer 1989, 141 (140-176)). Masonų ideologijoje per išplètotą simbolių ir ritualų sistemą atsiskleide draugijos siekiai, artimi Švietimo epochos idealams - laisvo, doro ir apsišvietusio žmogaus kūrimas.

Savo struktūra masonų draugija buvo tarptautinè organizacija, puoselëjanti ryšius su kitų valstybių ložèmis. Draugijos narius vienijo ne tik simbolių sistema, bet ir jos narių tarpusavio vizitavimas, korespondencija, nepaisant priklausomybės skirtingoms ložèms ar valstybėms. İvardydami save kaip broliją ir siekdami išgyvendinti visuomenès ydas, masonai iškẻle dvasini imperatyvą - jiems buvo svarbus nuolatinis asmens tobulèjimas, 
vertybių ugdymas, humanistinių idealų akcentavimas. Daug dėmesio skiriama švietimui, kurio rẻmimas buvo vienas iš masonų draugijos prioritetų ir filantropinių siekių (Tohvri 2012, 94 (93-101)). Remdamiesi simbolių sistema, žmogaus tobulinimą laisvieji mūrininkai išreiškẻ dvasinès, humanistinès šventyklos kūrimu, moralinio tobulejimo siekiamybe, kurią parodè masoniškieji laipsniai. Laisvosios mūrininkijos pradžia siejama su 1717 m. birželio 24 d., kada keturios Londono masonų ložès susivienijo i vieną Didžiąją ložę ir prisidejjo prie esminio Švietimo epochos deklaruoto lozungo - šviesos skleidimo žmonijai. Ilgainiui ložès išplito visoje kontinentineje Europoje ir tapo viena populiariausių Švietimo amžiaus draugijų, kuriai priklause pasaulietiniai ir dvasiniai aristokratai. Vokietijos masonų istorijos pagrindai buvo padèti 1737 m., ịsikūrus Hamburgo ložei (Loge d'Hambourg). Vèliau laisvieji mūrininkai išplito visoje Vokietijoje (Reinalter 1989, 11 (9-35)). Rytų Prūsijoje didžiausias masonų raiškos centras (freimaurerische Hochburg) buvo Karaliaučius, kuriame pirmoji Triju inkaru (Aux trois Ancres) ložè buvo ịkurta 1746 m., o gavus pritarimą iš Berlyno didžiosios ložès Po trimis gaubliais ( $\mathrm{Zu}$ den drei Weltkugeln), 1760 m. ịkurta ložè Po trimis karūnomis (Zu den drei Krönen) (Gerlach 2009, 230). Iki 1806 m. Rytų Prūsijos ložèms priklausè apie 1520 narių. Tarp jų - žymus Mažosios Lietuvos lietuvių kultūros atstovas, Karaliaučiaus universiteto profesorius, raštijos ir kultūros veikejjas Martynas Liudvikas Rèza. Akademinejje Karaliaučiaus universiteto aplinkoje įsitvirtinęs Rėza tapo bene ryškiausia Švietimo epochos asmenybe, atstovavusia lietuvių raštijai ir ją stropiai puoselejusia. Šio straipsnio tikslas - atskleisti masoniškuosius Rėzos ryšius, vienaip ar kitaip veikusius jo lituanistinę veiklą, ir masonų draugijos sąsajas. Straipsnyje taikomi aprašomasis ir interpretacinis metodai.

\section{Istoriografija}

Faktas, kad Rėza priklausė masonų draugijai, yra visuotinai žinomas. Pirmiausia apie tai parašè Laima Kiauleikytè (2001, 22-32; 2003, 126143). Apie Rèzos priklausymą masonų draugijai monografijoje užsiminè Albinas Jovaišas (1969b), ši faktą savo publikacijoje taip pat minejo Nijolè Strakauskaitė (2007, 66-84). Straipsnị apie masonų ịtaką Rėzai paskelbė Irena Skomskienè (2010). Rėzos narystę draugijoje liudija išlikę Karaliaučiaus masonų ložès Po trimis karūnomis dokumentai (VUB RS). Vokiečių 
istoriografijoje, be bendrųju darbų masonų tema (Reinalter 1989b, Gerlach 2009, Gerlach 2014 ir kt.), paskelbta vertingos medžiagos apie konkrečių Prūsijos masonų ložių istoriją ir jų veiklą (Fischer 1910, VUB RS). Rèzos biografiją, mokslinę ir kultūrinę jo veiklą patikslina Liucijos Citavičiūtès naujai parengti ir išleisti Rẻzos raštuc tomai (2011, 2013, 2014). Juose publikuojami Rèzos laiškai garsiems intelektualams, recenziju apie pasirodžiusius profesoriaus veikalus vertimai.

Rèza - Karaliaučiaus masonų draugijos narys

Karaliaučiaus masonų ložès Po trimis karūnomis kronikoje Rèza apibūdintas kaip Karaliaučiaus universiteto teologijos profesorius, nusipelnęs lietuvių tautai - išleidęs liaudies dainų rinkinį, parengęs lietuviškos Biblijos leidimą, o savo prieraišumą minètam universitetui įrodęs studentų bendrabučio Rhesanium ịkūrimu (Fischer 1910). Visuotiniame masonų žinyne Rèzos indèlis ị lietuviškumo puoselejjimą pabrèžtas Lietuvių kalbos katedros įsteigimu, o pats Rèza apibūdintas kaip ištikimas masonų draugijos narys iki mirties (bis zu seinem Tode treu geblieben) (Lenning 1901, 244).

I minėtą Karaliaučiaus ložę Rėza įstojo 1806 m. Praejjus trejiems metams po i̇stojimo (1809), Rėza jau buvo pasiekęs III (aukščiausią pagal anglišką sistemą) meistro pakopos laipsni (VUB RS, 18). 1811-1812 m. profesorius ėjo parengiamojo brolio (Vorbereitender Bruder) pareigas, o vèliau (1816-1819 m.) tapo ložès kalbètoju / oratoriumi (der Redner) (Fischer 1910, 239). Dvasinis tobulinimasis Rèzai nebuvo vien tik kontempliatyvus dalykas, pagrịstas filosofiniais svarstymais - dvasinio tobulinimosi užmojus jis iggyvendino eidamas kalbėtojo pareigas (Fischer 1910, 239). Ložès broliams, kultūriniam ir socialiniam Karaliaučiaus elitui, Rėza skaitė pranešimus, galèjo tarti žodi ypatingomis progomis, kalbèti apie aktualias to meto problemas, savo idejas ir mintis skleisti didesniam intelektualų būriui. Reikètų manyti, kad Rėza ir ložèje buvo iškalbingas pamokslininkas, oratorius, vengiantis šabloniškų pamokslu iš lapelio, nes „,malda iš širdies, nors paprasta, kukli, yra daug veiksmingesnè nei iškilmingiausia, bet perskaityta iš popieriaus“ (Rèza 2000, 67). Masonišką mintį Rėza skleidẻ savo pranešimuose, kuriuose nevengė krikščioniškų motyvų (minejjo pranašą Mozę) (Fischer 1910, 255). Profesorius pasižymėjo svarbiausiomis laisvųjų mūrininkų savybėmis - neeiliniu išsilavinimu, dorumu, polinkiu 
ị filantropiją. Reikètų manyti, jog Rèzai taip pat buvo svarbus dvasinis ugdymas. $1816 \mathrm{~m}$. vasario $6 \mathrm{~d}$. ir kovo $7 \mathrm{~d}$. savo sakytose kalbose ložès darbo metu Rèza teigè, kad laisviesiems mūrininkams yra svarbus dvasinis gyvenimas, o masonystę įvardijo kaip patị svarbiausią mokslą, meną ir mokyklą (das wahre geistige Leben als das einzige, was der Maurerei not tue. Sie sei eine Wissenschaft aller Wissenschaften, eine Kunst aller Künste, eine Schule aller Schulen) (Fischer 1910, 243).

Masonuc įtaka Rèzai

Rėzos priklausymas to meto apsišvietusiai intelektualų draugijai, deklaravusiai aukštas moralines normas, mokslą ir lavinimąsi laikiusiai vienu svarbiausių dalykų, galèjo būti nulemtas dar studijų metais suformuotos pasaulèžiūros. Neatmetama prielaida, jog Rėzą ì draugijos veiklą pastūmèjo dèstytojų, Karaliaučiaus universiteto profesorių, priklausiusių masonams, ittaka. Universitete Rèza lankè teologijos profesoriaus, generalinio superintendento ir Karaliaučiaus Kaukoles ir fenikso (Zum Todtenkopf und Phönix) masonų ložès nario Johanno Ernsto Schultzo (Johann Ernst Schultz, 1742-1806) 1778-1806 m. vadovaujamą Lietuvių kalbos seminarą ir moralinès filosofijos paskaitas. Vadovaudamas seminarui Schultzas jau buvo Karaliaučiaus masonų ložès Kaukolè ir feniksas, kuriai priklausė 1773-1806 m., narys (Hieber 1897, 321). Universitete Rèza taip pat klausėsi Karaliaučiaus filosofo Imannuelio Kanto (Imannuel Kant, 1724-1804) paskaitų, o jo novatoriškos idejjos ir raginimas nuolat mokytis mąstyti filosofiškai formavo studentų pasaulèžiūrą (Manthey 2006, 167). Nors Kantas nebuvo masonų draugijos narys, bet jo ittaka to meto apsišvietusiems intelektualams, studentijai ir ložès Po trimis karūnomis nariams didelè. Daugelis šiai ložei priklausiusių narių - buvę Kanto mokiniai, bičiuliai, brendę jo filosofinių idejjų aplinkoje, dalyvavę garsiuosiuose filosofo organizuotuose užstalès pokalbiuose (Tischgenossen). Kanto pietų pokalbiuose dalyvaudavo aukšti Prūsijos valdžios pareigūnai, verslininkai, tačiau svarbiausi dalyviai buvo vokiečių rašytojas, Karaliaučiaus burmistras, ložès Po trimis karūnomis narys Theodoras Gottliebas von Hippelis (Theodor Gottlieb von Hippel, 1741-1796), garsus Prūsijos valdininkas, švietèjas, rašytojas, tos pačios masonų ložès narys Johannas Georgas Scheffneris (Johann Georg Scheffner, 1736-1820), Karaliaučiaus universiteto poezijos profesorius, švietejas, minètai ložei priklausęs Johannas Gotthelfas Lindneris (Johann 
Gotthelf Lindner, 1729-1776). Kanto užstalès pokalbiai pritraukè ir daugiau ložès Po trimis karūnomis narių, tarp kurių - garsus Karaliaučiaus knygininkas ir spaustuvininkas Johannas Jacobas Kanteris (Johann Jacob Kanter, 1738-1786), pastarojo mokinys, spaustuvininkas Johannas Friedrichas Hartknochas (Johann Friedrich Hartknoch, 1740-1789), garsiosios dinastinès Hartungų spaustuvès įpèdinis Gottliebas Lebrechtas Hartungas (Gottlieb Lebrecht Hartung, 1747-1797) (Gerlach 2009, 271-272). Domejjimąsi su masonais glaudžiai susijusio Kanto idejjomis rodo ir Rėzos moksliniai darbai. Jau būdamas masonų ložès narys, gerai susipažinęs su laisvųjų mūrininkų ideologija ir Kanto filosofija, 1807 m. Rèza apgynè disertaciją „Apie šventųių knygų moralès aiškinimą pagal Kantą“, vẻliau savo kūryboje ne kartą minèjo žymųji filosofą. Su dideliu susidomèjimu Rèza klausėsi garsaus profesoriaus, žymiausio Kanto mokinio, ložès Po trimis karūnomis nario Christiano Jakobo Krauso (Christian Jakob Kraus, 1753-1807) praktinès filosofijos ir ekonomikos paskaitų, kuriose, veikiamas masoniškų interesų ir keldamas svarbius socialinius klausimus, profesorius studentams darè didelę įtaką visoje Vokietijoje (Krollmann 1974, 361; Schubert 1855, 248 (241-336)). Žavejjimąsi Krausu Rėza ịprasmino raštu - dedikavo eilèraštị. Savo kurtų eilių Rėza nevengè skirti ir kitiems Karaliaučiaus ložès Po trimis karūnomis broliams - Hippeliui, Prūsijos monarchui Friedrichui II (Friedrich II, 1712-1786) ${ }^{2}$.

Tikètina, jog Rėzos priklausymas elitinei eruditu draugijai galèjo būti gerai apgalvotas ir jam parankus sprendimas (Strakauskaite 2007, 77 (6684)). Pirmiausia - moksliniais tikslais. Masonu draugija buvo ta vieta, kur Rèza galèjo dvasiškai tobulèti, plèsti erudiciją, dalytis / gauti įvairios pasaulietinès literatūros, juolab jog ložè turèjo savo biblioteką (Fischer 1910, 38). Masonai, ypatingą dèmesị skirdami knygoms, dèl asmeninès savišvietos, moralinio tobulejjimo ir dvasinio sielos turtinimo kaupe bibliotekas. Rèza taip pat buvo sukaupęs didelę asmeninę biblioteką, jo pastangomis biblioteka buvo pradėta formuoti ir Karaliaučiaus Lietuvių kalbos seminare $^{3}$. Be to, draugijai priklause intelektualūs, apsišvietę asmenys, tarp jų - leidejai ir spaustuvininkai, be kurių indèlio neįsivaizduojama litua-

2 Rèzą žavejjo Prūsijos valdovo apsišvietusi asmenybè, gebejjimas kurti nemirtingus kūrinius. Karalių Rėza laikè kuriančiu genijumi (Rèza 2000, 87).

3 Martyno Liudviko Rèzos asmeninès bibliotekos katalogo fotokopijos (Rėza 2014, 477; Citavičiūtè 2004, 115-118). 
nistikos plètotė. Reikètų manyti, jog narystė draugijoje Rėzai buvo svarbi. 1818 m. spalio 15 d. sakytoje kalboje ložès darbo metu Rèza iškèlè amžinąsias masonų idejjas (Unvergänglichkeit maurerischer Ideen), sveikino Prūsijos karalių Friedrichą Wilhelmą IV (Friedrich Wilhelm, 1795-1861) ir pažymėjo, jog prie sėkmingo ložès gyvavimo prisideda ir karaliaus malonė (Fischer 1910, 261).

Rèzos lietuviuckalbos puoselèjimo atgarsiai Didžiojoje Lietuvoje

XIX a. pradžioje Prūsijoje buvo vykdoma germanizacinė politika. Ji buvo nukreipta prieš tautines mažumas. Kultūros veikèjai (pažangioji visuomenès dalis) reagavo opoziciškai. Rėza buvo aktyvus lietuvybės gynẻjas. Profesorius uoliai gynė Karaliaučiaus universitete veikusį Lietuvių kalbos seminarą, teikè planus jo reformoms (Citavičiūtė 2004, 107).

Rèzos kovõs su germanizacija, nusistatymo prieš lietuvių kalbos išstūmimą iš viešojo gyvenimo Rytų Prūsijoje atgarsiai sklido Didžiojoje Lietuvoje. Lietuviu kalbos puoselëjimo klausimas taip pat rūpejo Vilniaus universiteto graikų ir lotynų kalbų profesoriaus, žymaus Lietuvos masono Gottfriedo Ernesto Groddecko (Gottfried Ernest Groddeck, 1762-1825) padejjèjui, universiteto bibliotekos adjunktui, Vilniaus masonų ložès nariui Kazimierui Kontrimui (Kazimier Kontrym, 1777-1836) (Bučys 2009, 172, 186). 1822 m. gegužès 29 d. Kontrimas tuometiniam universiteto kuratoriui Adomui Jurgiui Čartoriskiui (Adam Jerzy Czartoryski, 1770-1861) įteikè projektą dẻl lietuvių kalbos paskaitu įvedimo Vilniaus universitete. Lietuvių kalbos katedros įsteigimo būtinybę Kontrimas pabrèžè primindamas, jog Karaliaučiaus akademijoje jau keletas šimtmečių veikia Lietuvių kalbos katedra. Dėstyti lietuvių kalbą bibliotekos adjunktas siūlè skirti Leoną Uvainị (Leon Uwoyń, 1755-1828), studijavusį Karaliaučiuje ir Varšuvoje. Pastarasis buvo $1817 \mathrm{~m}$. Raseiniuose įsteigtos masonų ložès Palemonas narys (Bučys 2009, 177). Siūlyme Kontrimas teigè, jog Uvainis yra eruditas, mokantis senovès kalbas, turintis savo biblioteką, daug dirbantis ir rašantis lietuvių kalbos etimologinị žodyną. Jeigu Uvainis atsisakytų, Kontrimas siūlè pakviesti mokytą vokietį iš Karaliaučiaus (Žulys 1978, 34, 37, 38 (30-38)). 1825 m. dẻl universiteto pertvarkų Literatūros ir laisvųjų menų fakultetas sušaukė posėdị, kuriame dalyvavo fakulteto vadovybė (Merkys 1972, 63). Tarp vadovybės narių būta laisvųjų mūrininkų - pro- 
fesorius, Vilniaus universiteto adjunktas, masonų ložès Uolusis lietuvis narys Leonas Borowskis (Leon Borowski, 1784-1846) ir Vilniaus universiteto dailès profesorius, minètos masonų ložès narys Janas Rustemas (Jan Rustem, 1762-1835) (Bučys 2009, 167, 170). Kontrimo teiktam projektui carinè valdžia leidimo nedavè ir planas įvesti lietuvių kalbos paskaitas universitete taip ir liko neigyvendintas.

Rèzos masoniškas broliškumas atsiskleidè bandant tiesti kultūrinį tiltą tarp Mažosios ir Didžiosios Lietuvos. Apie Rėzos užmojus rinkti folklorinę medžiagą ne tik Rytų Prūsijoje, bet ir Didžiojoje Lietuvoje rašè laikraštis Dziennik Wileński (Zawadski 1817, 505-506 (473-584)). 1805-1825 m. ši laikraštị spausdino Vilniaus masonų ložiu nario Juozapo Zavadskio (Józef Zawadski, 1781-1838) spaustuvè (Bučys 2009, 171). Zavadskis buvo Vilniaus universiteto spaustuvininkas, turejo savo knygyną. Spaustuvininko paslaugomis dažnai naudojosi masonai (Kiauleikytė 2001, 28-29 (22-32)). Minètame laikraštyje buvo rašoma, kad Rėza renka tautosakinę medžiagą, užrašinejja senas lietuviškas dainas, planuoja kelionę į Žemaitiją ir Lietuvą. Žinutẻ laikraštyje atsirado per Groddecką, kuris Rėzai galèjo būti žinomas kaip Vilniaus universiteto prefektas, žymus to meto profesorius, Vilniaus masonų ložès narys (Bučys 2009, 168, 172). 1817 m. Rèza jam parašè laišką ir nusiuntė „Lietuviškos Biblijos istoriją“.

Rèzos ir Johanno Gottfriedo Jordano ryšiai

Masonų broliškumas, kaip vienas esminių laisvosios mūrininkijos siekių, pasireiškè per draugijos narių korespondenciją ir vizitacijas. Rėza korespondavo su artimu Kristijono Donelaičio (1714-1780) bičiuliu, Karaliaučiaus universiteto auklètiniu, intelektualu, žinomu lietuvių raštijos darbuotoju, valdžios paskirtu lietuviškuc knygų cenzoriumi, Valtarkiemio parapijos pastoriumi, nuo 1799 m. Karaliaučiaus masonų ložès Po trimis karūnomis nariu Johannu Gottfriedu Jordanu (Johann Gottfried Jordan, 1753-1822) (Fischer 1910, 502). 1776-1779 m. Jordanas buvo İsruties

\footnotetext{
Leidinys, kaip dovana Vilniaus universiteto bibliotekai, buvo įregistruotas $1817 \mathrm{~m}$. Universiteto bibliotekoje taip pat buvo saugoma Rėzos rankraštinė „Bažnyčios istorija“, kurios tikslus atsiradimo laikas bibliotekoje nežinomas. 1834 m. rugsėjo 21 d. „Dovanų knygoje Vilniaus universiteto bibliotekai“ ji buvo aprašyta kartu su kitais rankraščiais (žr. Pacevičius 2010, 115, 190).
} 
precentorius, nuo $1779 \mathrm{~m}$. dirbo kunigu Valtarkiemyje, o nuo $1811 \mathrm{~m}$. buvo Galdapès superintendentas.

Valtarkiemio pastorius svarbiu indèliu prisidejo prie lituanistikos plètotès. Jis buvo vienas didžiausių Rézos talkininkų - pagelbejjo rengiant trečiąją Rèzos Biblijos laidą (1816), buvo vienas iš lietuvių liaudies dainų pateikejjų. Tikètina, kad Jordanas taip pat prisidejjo prie pirmosios Rėzos lietuviškos publikacijos - anonimiškai 1810-1818 m. paskelbtos 300 eilučiu Kristijono Gotlybo Milkaus (Christian Gottlieb Mielcke, 1733-1807) istorinès poemos „Pilkainis“ (Kaunas 1986, 7). Istoriografijoje aptinkama prielaidų, jog poemą Rėza gavo per Jordaną, kuris, eidamas lietuviškų knygų cenzoriaus pareigas, buvo sukaupęs ịvairių su lituanistika susijusių rankraščiu (Sidabraitė 2004, 323-324 (316-333)). Jordano dèka Rėzą taip pat pasiekè Donelaičio pasakéčios (Citavičiūtè 2014b, 85) ir „Metu““ rankraščiai. Valtarkiemio pastorius buvo geras Donelaičio bičiulis, todèl galèjo pagelbèti Rèzai renkant biografijos žinias apie Donelaiti (Jovaišas 1969, 131).

Neatmestina prielaida, jog Rėzą ir Jordaną galèjo suvesti masoniškieji ryšiai. Nuo 1785 m. Rėzą globojo Kaukẻnų parapijos precentorius, raštijos darbuotojas Christianas Davidas Wittichas (Christian David Wittich, 1751-1824). Kaukènai, kur mokyklą lankè Rėza (1785-1791 m.), priklausė Pakalnès apskričiai. Jordanas gyveno ir veikė İsruties apskrityje. Atidžiau gilinantis į Rėzos ir Jordano ryši, akivaizdu, jog skiriasi Rèzos ir Jordano studijų metai Karaliaučiaus universitete. Pastarasis Karaliaučiuje studijavo nuo 1769 m., o vèliau grị̌o dirbti kunigu ị Valtarkiemị. Rèza i universitetą ịstojo $1795 \mathrm{~m}$. Po studijų jis liko gyventi ir dirbti Karaliaučiuje. İ Karaliaučiaus masonų draugiją Po trimis karūnomis Jordanas įstojo $1799 \mathrm{~m}$. Praejus metams po Rèzos įstojimo ị draugiją (1806 m.), Jordanas Rèzai įteikè Donelaičio „Metų“ rankraštic (1807 m.) (Kaunas 2016, 137).

Rèzos bendradarbiavimas su spaustuvininku Georgu Friedrichu Hartungu

Nuo XVIII a. vidurio žymiausia ir didžiausia lietuviškų knygų leidybos įmonè, turejjusi įvairių privilegijų, buvo Hartungu dinastinè spaustuvè Karaliaučiuje. Spaustuvès atstovai Johannas Heinrichas Hartungas (Johann Heinrich Hartung, 1699-1756), Georgas Friedrichas Hartungas (Georg Friedrich Hartung, 1782-1849) ir Gottliebas Lebrechtas Hartungas 
priklausė masonų draugijai (Fischer 1910, 497; Gerlach 2009, 234-235). Pastarasis Karaliaučiaus ložèje Po trimis karūnomis net buvo pasiekęs aukščiausiąij - meistro laipsni (VUB RS, 36, 40). Hartungų i̇monė buvo viena moderniausių spaudos i̇monių, sudaryta iš knygų ir periodikos leidyklos, spaustuvès bei knygyno (Kaunas 2016, 138). Ju spaustuveje buvo išspausdinti svarbūs lituanistiniai Pilypo Ruigio (Philipp Ruhig, 1675-1749), Povilo Frydricho Ruigio (Paul Friedrich Ruhig, 1725-1781), Kristijono Gotlybo Milkaus, Gotfrydo Ostermejerio (Gottfried Ostermeyer, 1716-1800) ir kitų žymių lietuvių raštijos veikejjų darbai. Minètoje spaustuvejje buvo perspausdinama Danieliaus Kleino (Daniel Klein, 1609-1666) maldaknygé ir vẻlesnių parengèjų nuolat pildytas giesmynas, įvairi dorovinẻ ir religinẻ lietuviška lektūra. Karališkos spaustuvès privilegiją turejjusi akademinė Hartungų spaustuvė (Hartungsche Hof-und Universitäts-Buchdruckerei) taip pat spausdino Karaliaučiaus profesorių traktatus (Citavičiūtè 2013, 20 (13-31)). Spaustuvejje buvo išleistos svarbios Rėzos mokslinès studijos, anuomet vadintos pranešimais ar disertacijomis (Petkūnas 2011, 5-19 (1-27)). İdomu tai, jog 1811 m., Rėzai ginantis vieną iš jo parengtų disertacijų, diskusijos pirmininkas buvo nuo $1781 \mathrm{~m}$. Karaliaučiaus masonų ložei Po trimis karūnomis priklausęs vokiečių teologas Johanas Christophas Wedeke (Johann Christoph Wedeke, 1755-1815) (Fischer 1910, 531).

Hartungu spaustuveje taip pat pasirodè reikšmingiausi Rėzos darbai pirmasis Donelaičio „Metų“ leidimas (1818), rinkinys „Dainos“ (1825), mokslinè studija „Lietuviškos Biblijos istorija“ (1816) ir dviejų dalių veikalas „Filologinès-kritinès pastabos lietuviškai Biblijai: naujojo leidimo lietuviško teksto redagavimo komentarai“ (1816), Ezopo pasakéčios „Aisopas, arba Pasakos" kartu su pirmąja Donelaičio pasakéčiu publikacija (1824). Pastarasis rinkinys susidejo iš Ezopo ir septynių iš vokiečiu kalbos proza verstų pasakéčių. Trys pasakéčios buvo Christiano Fürchtegotto Gellerto (Christian Fürchtegott Gellert, 1715-1769), kitos trys buvo verstos iš nenustatytų šaltinių ir viena - vokiečiu poeto, pasakètininko, Leipcigo masonų ložès nario Magnuso Gottfriedo Lichtwerio (Magnus Gottfried Lichtwer, 1719-1783) (Gädicke 1818, 314-315).

Rèzos leidybinèje veikloje svarbiausias yra Georgas Friedrichas Hartungas. Pastarasis buvo garbingas Karaliaučiaus inteligentijos atstovas, miesto tarybos narys, perėmęs šeimos spaustuvès verslą ir jam vadovavęs nuo 1817 m. (Weisfert 1975, 88). 1815 m. spaustuvininkas įstojo į Kara- 
liaučiaus masonų ložę, todèl iki pasirodant svarbiausiems Rėzos veikalams abu intelektualai jau buvo gerai pažǐstami. Hartungas turejjo būti girdèjęs kalbètojo Rèzos (1816-1819) pranešimus ložès darbų metu. Apie bendradarbiavimą su Hartungu Rėza yra užsiminęs viename iš rašytų laiškuc vokiečių literatūros klasikui Johannui Wolfgangui von Goethe'ei (Johann Wolfgang von Goethe, 1749-1832) $)^{5}$. Kreiptis ị Goethe Rèzą paskatino noras gauti rekomendaciją rengiamam „Dainų“ rinkiniui. Asmeniškai Rėza Goethe's nepažinojo, i i i kreipèsi per tarpininkus. Stengdamasis užmegzti svarbius lituanistinius ryšius, Rèza tikèjosi platesnès leidinio sklaidos. 1820 m. spalio 14 d. rašytame laiške Rèza Goethe'ei priminè, jog dèmesị ì lietuvių liaudies dainas yra atkreipęs „,nemirtingasis Kantas, pagyręs jas Milkaus lietuvių kalbos žodyno pratarmėse“, taip pat Gottholdas Ephraimas Lessingas (Gotthold Ephraim Lessing, 1729-1781) ir Johannas Gottfriedas Herderis (Johann Gottfried Herder, 1744-1803). Pastarieji priklausẻ laisvųjų mūrininkų draugijai (Lenning 1900, 608; Fischer 1910, 499). Rèzai galèjo būti žinoma, jog nuo $1780 \mathrm{~m}$. Goethe taip pat buvo Weimaro masonų ložès narys. Veikiausiai neatsitiktinai, $1820 \mathrm{~m}$. spalio $14 \mathrm{~d}$. Goethe'ei siųstame laiške, Rèza pabrèžè ne tik klasiko meilę literatūrai, bet ir jo didžiadvasišką kilnumą - svarbiausią laisvųjų mūrininkų ideologijos pamatą. Užsiminęs apie lietuvių liaudies dainų rinkinio reikalingumą, Rèza Goethe’s prašè, „,kad į vokiečiu mokslo pasauli jas įvestų ranka vyro, kurị Vokietija be jokio pataikavimo pavadino poetų kunigaikščiu ir savo literatūros hercogu“. Nesulaukęs jokio atsakymo iš Goethe's, Rèza jam parašè dar vieną laišką. 1826 m. kovo 20 d. rašytame laiške Goethe'ei Rèza teigè, jog ,su dideliu vargu pavyko ịkalbèti Hartungą tas niekinamas dainas šị kartą išspausdinti savo lèšomis, be honoraro sudarytojui“. Laiške Rèza išreiške abejonę dèl Hartungo lëšų atgavimo, nes pastarasis esąs tik spaustuvininkas, gerai nenusimanantis knygų prekybos reikaluose. Hartungas ir visa jo dinastinè spaustuvė Goethe'ei galèjo būti žinoma, juolab jog garsieji Hartungų spaustuvininkai buvo Karaliaučiaus masonų ložès Po trimis karūnomis nariai.

Hartungo ir Rėzos santykiai buvo broliški ir bičiuliški. 1825 m. Karaliaučiaus profesorius pagelbejo Hartungui, kai šis rengė naują informacinị leidinị apie Karaliaučiaus universiteto profesorius ir studentus. Savo

5 Straipsnyje naudotasi Rėzos rašytų laiškų Goethe'ei vertimo rankraščiais. Dèkoju dr. Liucijai Citavičiūtei už maloniai suteiktą leidimą pasinaudoti vertimo rankraščiais. 
spaudinyje apie universitetą Hartungas Rėzą pristatė kaip auksinio medalio turètoją, kariuomenès pamokslininką, rašytoją ir poetą, labai nusipelniusị lietuvių kalbai (Hartung 1825, 70). Dèkingumą Rèzai Hartungas ịprasmino savo leidinyje. Knygoje esančioje padèkoje spaustuvininkas išvardijo leidinio talkininkus, dèkojo jiems už palaikymą ir bendradarbiavimą (Hartung 1825, 5).

Rèzos darbų sklaida

Prie Rèzos lituanistinių darbų iškilimo prisidejjo anonsai, leidinių sklaida ir recenzijos (Citavičiūtè 2014a, 30 (19-51); 2017a, 161 (160-202); 2017b, 150-151 (149-159)). Pirmosios laidos „Metus“ savo turètose i̇monèse Karaliaučiuje ir Gumbinèje platino Hartungas. Spaustuvininkas leidini sieké pristatyti didesnei rinkai. Dalį tiražo jis perdavė žinomai lietuviškų knygų leidejjai Tilžeje - Johanno Heinricho Posto (Johann Heinrich Post, 1789-1842) spaustuvei. „Metus“ pardavinėjo ir kiti Prūsijos knygynai. Rèzos leidinių sklaidos ir populiarinimo procese taip pat neapsieita be masoniškųju atgarsių. Leidiniu prekiavo garsaus vokiečių knygininko, bibliografo, leidèjo, Berlyno masonų ložès nario Theodoro Johanno Christiano Friedricho Enslino (Theodor Johann Christian Friedrich Enslin, 1787-1851) (Nachweis... 1844, 54) knygynas-leidykla Berlyne. Minètas knygininkas prisidejjo prie lietuviškų veikalų išleidimo. Po Rėzos mirties komisiniais pagrindais Enslinas išleido Frydricho Kuršaičio (Friedrich Kurschat, 1806-1884) parengtą antrąją Rėzos „Dainų“ laidą (1843), vèliau - Kuršaičio „Lietuvių kalbos tyrinèjimo“ antrąji sąsiuvinị „Lietuvių kalbos garsų ir kirčio mokslas“ (1849) (Kaunas 2016, 145). Prie „Metų“ sklaidos prisidejo ir parengèjas Rèza. Dalị leidinio egzempliorių profesorius išdalijo mokslo įstaigoms, recenzentams, privatiems asmenims (Friedrichui Wilhelmui Christianui Karlui Ferdinandui von Humboldtui (Friedrich Wilhelm Christian Karl Ferdinand von Humboldt, 1767-1835), Scheffneriui).

XIX a. susidomėjimas lituanistika buvo juntamas slavų šalyse. Prie Rèzos darbų sklaidos Lenkijoje prisidejjo žymus lenkų poetas, masonų draugijos narys Kazimieras Brodzinskis (Kazimierz Brodziński, 1791-1835) (Łempicki 1932, 232 (232-247)) ir lenkų istorikas, taip pat masonas Juozapas Ignotas Kraševskis (Józef Ignacy Kraszewski, 1812-1887) (Wotowski 1926, 41). Jovaišas nurodo, jog Brodzinskis domejjosi lietuvių liaudies 
poezija ir ją populiarino. Drauge su talkininkais jis išverte ir paskelbė Rèzos parašytą straipsni „Apie lietuvių liaudies poeziją“ (Jovaišas 1969b, 44). Lietuvių kalba ir tautosaka taip pat domino Kraševskį, kuris savo leistuose lenkiškuose leidiniuose pateike nemažai lietuviškų dainų (Jovaišas 1969b, 311). Pastarasis taip pat buvo Rėzos „Dainų“ vertejjas ị lenkų kalbą.

Rėzos spaudai parengta Donelaičio poema „Metai“ ir sudarytas liaudies dainų rinkinys sulauke plataus tarptautinio atgarsio. Palankias recenzijas paskelbė žymiausi Europos literatūriniai laikraščiai. Pirmasis atsiliepimas apie Donelaičio „Metus“ pasirode 1818 m. Karaliaučiaus karališkojo adresų biuro informaciniame biuletenyje (Citavičiūtè 2014a, 41 (19-51)). Tais pačiais metais Jenos universiteto profesorius Abrahamas Jakobas Penzelis (Abraham Jakob Penzel, 1749-1819) paskelbe „Metu““ recenziją ${ }^{6}$. Penzelis buvo garsus vokiečiu filologas, kartu su gerai žinomu Karaliaučiaus spaustuvininku, masonų ložès Po trimis karūnomis nariu Kanteriu leido laikraštį, domejjosi lituanistika, bičiuliavosi su garsiausiais Karaliaučiaus intelektualais, korespondavo su žinomu raštijos veikejju Ostermejeriu (Gerulaitienè 2008). Rèza ir Penzelis buvo pažistami asmeniškai. Pažintis užsimezgè per Scheffnerị, kuris bendravo su Penzeliu. Pastarasis ị Scheffnerị kreipèsi prašydamas lituanistinių knygų. Scheffneris rekomendavo Rėzą, su kuriuo taip pat buvo gerai pažistamas - abu priklausè tai pačiai Karaliaučiaus masonų ložei. İ ložę Po trimis karūnomis Scheffneris įstojo $1761 \mathrm{~m}$. ir kaip senos masonu grandinès veteranas (ein Veteran der großen Bundeskette) draugijai priklause iki mirties (1820) (Fischer 1910, 257). 1818 m. ložejje vykusio darbo metu Scheffneriui net teko pavaduoti kalbėtojo pareigas tuo metu ejjusį Rèzą. Savo sakytoje kalboje Scheffneris pabrèžė žmogaus tobulinimosi svarbą (Erkenne dich selbst) (Fischer 1910, 257). Penzeliui Rèza du kartus (1818 ir 1819 m.) siuntè lituanistinių knygų. Sumą, reikalingą knygų siuntai, Rėzai suteikè Karaliaučiaus universiteto kuratorius, Rytų Prūsijos ir lietuviškų apskričių oberprezidentas, masonų ložès Po trimis karūnomis garbès narys ${ }^{7}$ Hansas Jakobas von Auerswaldas (Hans Jakob von Auerswald, 1757-1833) ${ }^{8}$. Citavičiūtès teigimu, Rèzos ir Auerswaldo

6 Recenzijos vertimą žr. Rėza 2014, 272-277.

71818 m. spalio 15 d., po kalbėtojo Rėzos sakytos iškilmingos kalbos, ložè Po trimis karūnomis garbės nariais paskelbė šešis brolius. Tarp jų buvo Auerswaldas ir Scheffneris (žr. Fischer 1910, 261).

8 Antrasis Martyno Liudviko Rėzos laiškas Johannui Georgui Scheffneriui (Rėza 2014, 266). 
draugystė galëjo užsimegzti 1807 m. Karaliaučiaus universitete, Rėzai ginant disertaciją apie Kantą. Neatmetama prielaida, jog minimi asmenys galèjo būti pažǐstami ir anksčiau. İ Karaliaučiaus masonų ložę Rèza ịstojo 1806 m., o Auerswaldas šios ložès narys buvo nuo 1780 m. Nors Rėza ir Auerswaldas priklausè tai pačiai masonų ložei, kuri skatino narių tarpusavio broliškumą, tarp šių intelektualų veikiausiai neišvengta ir įtampos. 1809 m. Auerswaldas ministerijai Berlyne teike pasiūlymus dẻl Karaliaučiaus universiteto reformų būtinybès. Jo požiūris į lietuvių kalbos išsaugojimą nebuvo palankus. Karaliaučiaus universiteto kuratorius pabrèžè Lietuvos integravimo į vokiškąją Prūsiją klausimą, o kunigus ir mokytojus lietuvių kalbos mokyti ragino tik tol, kol ji visai išnyks (Citavičiūtė 2004, $105,109,124)$.

1825 m. recenzija apie „Dainu“ rinkini pasirodè Hartungo leistame vokiškame laikraštyje. Atsiliepime, kurio autorius nenustatytas, palankiai vertintas knygos pasirodymas, pabrèžtas teigiamas žymiausio Švietimo epochos vokiečiu literatūros kūrẻjo Lessingo, atkreipusio dèmesị ị lietuvių liaudies dainas, požiūris ${ }^{9}$. Apie Rèzos liaudies dainų rinkinị recenzijų pasirode $1826 \mathrm{~m}$. Tais metais Gettingeno laikraštyje atsiliepimą paskelbẻ garsus vokiečių filologas Jacobas Grimmas (Jacob Grimm, 1785-1863) ${ }^{10}$. Recenzijos buvo skelbiamos vokiečių (Berlyno), austrų mokslo žurnaluose (Citavičiūtė 2017b, 152 (149-159)) $)^{11} 1827$ m. Štutgarto žurnale recenziją išspausdino Goethe ${ }^{12}$. Tais pačiais metais atsiliepimų pasirodė Leipcigo literatūriniuose laikraščiuose ${ }^{13}$. Citavičiūtė daro prielaidą, jog vienos recenzijos, pasirodžiusios Leipcigo laikraštyje, autorius galèjo būti garsus vokiečiu rašytojas, visuomenès veikejjas, nuo 1814 m. Karaliaučiaus masonų ložei Po trimis karūnomis priklausęs Augustas Friedrichas Ferdinandas von Kotzebue (August Friedrich Ferdinand von Kotzebue, 1761-1819) (Fischer 1910, 505; Citavičiūtė 2017b, 156 (149-159)).

\footnotetext{
9 Recenzijos vertimą žr. Kaunas 1993, 134.

10 Recenzijos vertimą žr. Rèza 2014, 278-279.

11 Recenzijų vertimus žr.: Citavičiūtè 2017a, 162 (160-202); Citavičiūtè 2017a, 175 (160202).

12 Recenzijos vertimą žr. Jovaišas 1969, 362 (299-365).

13 Recenzijos vertimą žr. Citavičiūtė 2017a, 183, 186 (160-202).
} 


\section{Išvados}

Studijų metai yra vienas esminių asmenybės formavimosi periodų. Karaliaučiaus universiteto dèstytojai, darę Rèzai bene didžiausią įtaką (Johannas Ernstas Schultzas, Christianas Jakobas Krausas, Imannuelis Kantas), priklausė masonų draugijai arba buvo su ja artimai susiję. Intelektualinis Karaliaučiaus universiteto elitas priklause organizacijai, kurios tikslas buvo nuolatinis moralinis tobulejjimas, švietimo svarbos ir humanistinių idealų akcentavimas, dvasinių vertybių ugdymas. Neatmestina prielaida, kad šie déstytojai galèjo paskatinti Rèzos sprendimą priklausyti Karaliaučiaus laisviesiems mūrininkams, deklaravusiems moralines normas, mokslą ir lavinimąsi laikiusiems vienu svarbiausių dalykų. Tai galèjo būti nulemta dar studijų metais suformuotos pasaulèžiūros.

Priklausymas draugijai skatino Rėzos mokslinius interesus, taip pat sudare palankias sąlygas rengti ir leisti svarbiausius lituanistinius veikalus - pirmąji Donelaičio „Metų“ leidimą (1818), rinkinị „Dainos“ (1825), Ezopo pasakèčias „Aisopas, arba Pasakos“ kartu su pirmąja Donelaičio pasakéčių publikacija (1824). Priklausymas masonų draugijai Rėzai buvo palankus dẻl leidybinių tikslų ir savišvietos.

Rèza laisvųiu mūrininkų draugijai priklausẻ 35 metus (nuo $1806 \mathrm{~m}$. iki mirties 1841 m., t. y. daugiau nei pusę savo gyvenimo). 1816-1819 m. Rèza draugijoje buvo kalbètojas. Jo skaityti pranešimai Karaliaučiaus masonų ložès Po trimis karūnomis darbų metu rodo, kad Rèza draugiją laikè tobulumo viršūne.

Masonų draugijoje ịgytos pažintys padejo Rėzai rasti pagalbininkų ir talkininkų (Johannas Gottfriedas Jordanas, Georgas Friedrichas Hartungas, Johannas Georgas Scheffneris, Abrahamas Jakobas Penzelis) literatūriniams užmojams ịgyvendinti. Rėzos pažintis ir ryšiai su garsiausiu jo talkininku, tai pačiai Karaliaučiaus masonų ložei priklausiusiu Jordanu galèjo užsimegzti masonų draugijos dèka. I Karaliaučiaus ložę Jordanas ịstojo 1799 m., Rèza laisvųjų mūrininkų draugijos nariu tapo $1806 \mathrm{~m}$. Jordanas talkininkavo Rèzai rengiant trečiąji Biblijos leidimą (1816 m.), buvo vienas iš Rėzos folkloristinès veiklos pagalbininkų rengiant rinkini „Dainos“ (1825 m.). Jordano dèka Rèzą pasiekė Donelaičio pasakéčios ir „Metų“ rankraščiai (1807 m.). Taip pat Valtarkiemio pastorius pagelbejjo Rèzai renkant biografijos žinias apie Donelaitị. Be abejonès, tiek Rèzą, tiek Jordaną vienijo masonų draugijos idejjos, švietimo svarbos siekiai. 
Georgo Friedricho Hartungo, priklausiusio Karaliaučiaus ložei Po trimis karūnomis, spaustuveje Karaliaučiuje buvo išspausdinta didžioji dalis Rèzos parengtų svarbiausių leidinių - pirmasis Donelaičio „Metų“ leidimas (1818), rinkinys „Dainos“ (1825), Ezopo pasakèčios „Aisopas, arba Pasakos“ kartu su pirmąja Donelaičio pasakéčiu publikacija (1824). Dinastinejje Hartungų spaustuveje, kurios atstovai buvo Karaliaučiaus laisvieji mūrininkai, pasirode visi pagrindiniai Rėzos veikalai.

Rėzos lituanistinès veiklos masoniškuc atgarsių aptinkama ir ryšiuose su Didžiąja Lietuva. Jo kovõs su germanizacija ir lietuvių kalbos išstūmimo iš viešojo gyvenimo klausimas rūpèjo Vilniaus universiteto intelektualams, taip pat masonų draugijai priklausiusiems Gottfriedui Ernestui Groddeckui, Kazimierui Kontrimui. Rėza turèjo užmoju rinkti folklorinę medžiagą ne tik Rytų Prūsijoje, bet ir Didžiojoje Lietuvoje. Apie Rėzos tautosakos rinkimo planus rašė Vilniaus masonų ložèms priklausiusio Juozapo Zavadskio 1805-1825 m. leistas laikraštis Dziennik Wileński, kuriame informacija atsirado per masonams priklausiusį Vilniaus universiteto profesoriu Groddecką.

Populiarinant Rėzos išleistus darbus, svarbų vaidmenį suvaidino anonsai, platinimas ir recenzijos ne tik Vokietijoje, bet ir kaimyninèse valstybėse. Masonų draugijoje užmegzti ryšiai veikiausiai padejjo Rėzai vykdant parengtų lituanistinių leidinių sklaidą. Spaudinius Gumbinejje ir Karaliaučiuje platino Karaliaučiaus masonams priklausęs Hartungas. Rėzos parengtus „Metus“ Berlyne pardavinèjo Berlyno ložei priklausiusio masono Theodoro Johanno Christiano Friedricho Enslino knygynas. Prie Rėzos darbų sklaidos prisidejjo Lenkijos raštijos veikẻjai, masonai Kazimieras Brodzinskis ir Juozapas Ignotas Kraševskis, skelbę ir populiarinę Rėzos darbus Lenkijoje. Žymiausiuose Europos literatūriniuose laikraščiuose pasirodè palankių recenzijų apie Rėzos išleistus darbus. Dalis recenzentų priklausė masonams (Johannas Wolfgangas von Goethe, Augustas Friedrichas Ferdinandas von Kotzebue). Laisvųju mūrininkų draugijai priklausiusio Scheffnerio dèka Rèza užmezgè ryšius su Penzeliu. Pastarasis parašè „Metų“ recenziją.

\section{Literatūra}

Bučys 2009 - Žygintas Bučys. Masonai Lietuvoje: XVIII a. pabaiga-XIX a. pradžia. Vilnius: Lietuvos nacionalinis muziejus. 
Citavičiūtė 2004 - Liucija Citavičiūtè. Karaliaučiaus universiteto Lietuvių kalbos seminaras: istorija ir reikšmé lietuvių kultūrai. Vilnius: Lietuvių literatūros ir tautosakos institutas.

Citavičiūtè 2013 - Liucija Citavičiūtè. Žvilgsnis i nežinoma Rèzos kūrybinio palikimo dalị. In: Rèza M. L. Raštai, t. II, sud. L. Citavičiūtè. Vilnius: Lietuvių literatūros ir tautosakos institutas, 13-31.

Citavičiūtė 2014a - Liucija Citavičiūtè. Martynas Liudvikas Rèza - pirmasis Kristijono Donelaičio kūrybos publikuotojas. In: Rèza M. L. Raštai, t. IV, sud. L. Citavičiūtè. Vilnius: Lietuvių literatūros ir tautosakos institutas, 19-51.

Citavičiūtè 2014b - Liucija Citavičiūtè. Pirmoji lietuvių literatūros antologija „Aisopas, arba Pasakos“. In: Rèza M. L. Raštai, t. IV, sud. L. Citavičiūtė. Vilnius: Lietuvių literatūros ir tautosakos institutas.

Citavičiūtė 2017a - Liucija Citavičiūtè. Nežinomos recenzijos ir anonsai M. L. Rėzos lietuvių dainų rinkiniui Dainos oder Litthauische Volkslieder. In: Tautosakos darbai, t. 54. Vilnius: Lietuvių literatūros ir tautosakos institutas, 160-202.

Citavičiūtė 2017b - Liucija Citavičiūtè. Vokiečių ir lenkų recenzentų žvilgsnis ị M. L. Rèzos parengtą lietuvių dainų rinkinị Dainos (1825). In: Tautosakos darbai, t. 54. Vilnius: Lietuvių literatūros ir tautosakos institutas, 149-159.

Liucija Citavičiūtè. M. L. Rèzos rašytu laiškų (1820 ir 1826) vertimo rankraščiai.

Dotzauer 1989 - Winfried Dotzauer. Freimaurergesellschaften im Rheingebiet. Die Anfäge der freimaurerei im Westen des Alten Reiches. In: Reinalter H. Freimaurer und Geheimbünde im 18. Jahrhundert in Mitteleuropa. Frankfurt am Main: Suhrkamp, 140-176.

Fischer 1910 - Richard Fischer. 1760-1910. Geschichte der Johannisloge Zu den drei Kronen Or. Königsberg i Pr. Zur 150jährigen Gedenkfeier. Königsberg i. Pr.: Als Manuskript gedruckt.

Gädicke 1818 - Johann Christian Gädicke. Freimaurer-Lexicon, nach vieljährigen Erfahrungen und den besten Hülfsmitteln ausgearbeitet. Berlin: Gebrüder Gädicke.

Gerlach 2009 - Karlheinz Gerlach. Die Freimaurer im Alten Preußen 1738-1806. Die Logen in Pommern, Preußen und Schlesien. Innsbruck: Studienverlag.

Gerlach 2014 - Karlheinz Gerlach. Die Freimaurer im Alten Preußen 1738-1806. Die Logen in Berlin. Innsbruck: Studienverlag.

Gerulaitienè 2008 - Vilija Gerulaitienè. Abraham Jakob Penzel und sein Interesse an der litauischen Literatur in Ostpreußen. Annaberger Annalen, nr. 8. Prieiga internetu: http://annaberger-annalen.de/jahrbuch/2000/Annaberg\%20Nr.8\%20Kap7.pdf [žiūrèta 201808 30].

Gysi 1958 - Klaus Gysi. Erläuterungen zur Deutschen Literatur. Aufklärung. Berlin: Volk und Wissen.

Hartung 1825 - George Friedrich Hartung. Akademisches Erinnerungs-Buch für die welche in den Jahren 1787 bis 1817 die Königsberger Universität bezogen haben. Königsberg: Hartungschen Hofbuchdruckerei.

Hieber 1897 - Otto Hieber. Geschichte der Vereinigten Johannis-Loge zum Todtenkopf und Phönix zu Königsberg i. Pr. Im selbst Verlage des Verfassers.

Hof 1996 - Ulrich Im Hof. Švietimo epochos Europa. Vilnius: Baltos lankos.

Jovaišas 1969a - Albinas Jovaišas. Lietuvių literatūrinių ryšių raida XIX a. pradžioje. In: Literatūra ir kalba, t. 10. Vilnius: Vaga, 299-365.

Jovaišas 1969b - Albinas Jovaišas. Liudvikas Rėza. Vilnius: Vaga.

Kaunas 1986 - Domas Kaunas. Kaip ažuols drūts prie Nemunèlio. Vilnius: Vaga. 
Kotryna Rekašiūtè

Kai kurie Martyno Liudviko Rėzos

masoniškų ryšiu aspektai ir lituanistinè veikla

Kaunas 1993 - Domas Kaunas. Donelaičio žemès knygiai. Vilnius: Mokslo ir enciklopedijų leidykla.

Kaunas 2016 - Domas Kaunas. Kristijono Donelaičio atminties paveldas. Vilnius: Akademinè leidyba.

Kiauleikytė 2001 - Laima Kiauleikytė. XVIII-XIX a. sandūros Lietuvos masony muzikos kultūra. In: Menotyra, nr. 3 (24), 22-32.

Kiauleikytė 2003 - Laima Kiauleikytė. Freimaurerlied atgarsiai L. G. Rèzos (1776-1840) kūryboje. In: Kultūrologija, t. 10. Vilnius, 126-143.

Krollmann 1974 - Christian Krollmann. Altpreußische Biographie. Band I. Marburg / Lahn: N. G. Elwert.

Łempicki 1932 - Stanislaw Malachowski Łempicki. Wolnomularskie utwory Brodzińskiego. In: Pamiętnik Literacki: czasopismo kwartalne poświęcone historii i krytyce literatury polskiej, t. 29, nr. 1/4. Warszawa: Wydawnictwo Instytutu Badań Literackich Polskiej Akademii Nauk, 232-247.

Lenning 1900 - C. Lenning. Allgemeines Handbuch der Freimaurerei. Erster Band, A-L. Leipzig: Max Hesse.

Lenning 1901 - C. Lenning. Allgemeines Handbuch der Freimaurerei. Bd. 2. Leipzig: M. Hesse's Verlag.

Manthey 2006 - Jürgen Manthey. Königsberg. Geschichte einer Weltbürgerrepublik. München: Deutscher Taschenbuch.

Merkys 1972 - Vytautas Merkys. Simonas Daukantas. Vilnius: Vaga.

Nachweis... 1844 - Nachweis der Grossen Landesloge der Freimaurer von Deutschland zu Berlin für das Jahr 1844 und 1845, enthaltend den Bestand derselben am 24. Juni 1844: Angabe der zu eben dieser Zeit unter ihrem grossen Hammer arbeitenden Provinzial-Logen und deren Beamten, der von ihr gegründeten und berechtigten St. Andreas- und St. Johannis-Logen und der Freimaurer-Logen, mit welchen sie in Bezechung und Briefwechsel steht. Berlin: Dictericischen Buchdruckerei (E. S. Mittler).

Pacevičius 2010 - Arvydas Pacevičius. Pamirštoji mecenatystè 1792-1832. Dovanu Vilniaus universiteto bibliotekai knyga. Vilnius: Dabaexpo.

Petkūnas 2011 - Darius Petkūnas. Kunigas ir teologas Martynas Liudvikas Rèza. In: Rèza M. L. Raštai, t. I. Vilnius: Lietuvių literatūros ir tautosakos institutas, 1-27.

Reinalter 1989 - Helmut Reinalter. Einleitung. Zur Aufgabenstellung der gegenwärtigen Freimaurerforschung. In: Reinalter H. Freimaurer und Geheimbünde im 19. und 20. Jahrhundert in Mitteleuropa. Frankfurt am Main: Suhrkamp, 9-35.

Reinalter 1989 - Helmut Reinalter. Freimaurer und Geheimbünde im 18. Jahrhundert in Mitteleuropa. Frankfurt am Main: Suhrkamp.

Rèza 2000 - Martynas Liudvikas Rèza. Žinios ir pastabos apie 1813 ir 1814 metų karo žygius iš vieno Prūsijos armijos kapeliono dienoraščio. Vilnius: Lietuvių literatūros ir tautosakos institutas.

Rèza 2011 - Martynas Liudvikas Rèza. Raštai, t. I, sud. L. Citavičiūtė. Vilnius: Lietuvių literatūros ir tautosakos institutas.

Rèza 2013 - Martynas Liudvikas Rėza. Raštai, t. II, sud. L. Citavičiūtė. Vilnius: Lietuvių literatūros ir tautosakos institutas.

Rèza 2014 - Martynas Liudvikas Rėza. Raštai, t. IV, sud. L. Citavičiūtè. Vilnius: Lietuvių literatūros ir tautosakos institutas.

Schneiders 1997 - Werner Schneiders. Das Zeitalter der Aufklärung. München: C. H. Beck. 
Schubert 1855 - Friedrich Wilhelm Schubert. Aus dem Jahresberichte der Königl. Deutschen Gesellschaft zu Königsberg für d. J. 1854. In: Koch W. Neue preussische Provinzialblätter, Band. VII. Königsberg: E. J. Dalkowski, 241-336.

Sidabraite 2004 - Žavinta Sidabraitè. Kristijono Gotlybo Milkaus rankraščiai Lietuvoje. In: Senoji Lietuvos literatūra, kn. 17. Vilnius: Lietuvių literatūros ir tautosakos institutas, 316-333.

Skomskienė 2010 - Irena Skomskienè. Masonybès įtaka Liudviko Rèzos asmenybei ir kūrybai. In:Mokslo Lietuva, nr. 16, 17. Prieiga internetu: http://mokslasplius.lt/mokslo-lietuva/2006-2011/node/3020.html, http://mokslasplius.lt/mokslo-lietuva/2006-2011/ node/3056.html [žiūrèta 201808 30].

Strakauskaite 2007 - Nijolè Strakauskaitè. Martynas Liudvikas Rėza tautinio ir lokalinio identiteto fone. In: Martynas Liudvikas Rèza: epochų atspindžiai, sud. N. Strakauskaitė, S. Pocytė. Klaipėda: Klaipėdos universiteto leidykla, 66-84.

Tohvri 2012 - Epi Tohvri. Judejjimas „Pažinimo šviesos sklaida“ ir jo įtaka Tartu universiteto simbolikai XIX a. pradžioje. In: Laisvoji mūrininkija pasaulyje ir Lietuvoje: idëjos, istorija, asmenybès. Vilnius: Lietuvos nacionalinis muziejus, 93-101.

Vilniaus universiteto bibliotekos Rankraščiu skyrius (VUB RS), f. 72, b. 894.

Zawadski 1817 - Józef Zawadski. Dziennik Wileński, nr. 35. Wilno: J. Zawadski, 473-584.

Žulys 1978 - Vladas Žulys. Senasis universitetas ir lietuvių kalba. In: Mūsu kalba, nr. 6, 30-38.

Weisfert 1975 - Julius Nicolaus Weisfert. Lexikon für Königsberg und Ostpreussen. Hildeheim, New York: Georg Olms.

Wotowski 1926 - Stanisław Antoni Wotowski. Tajemnice masonerji i masonów. Warszawa: Wydawnictwo Księgarni F. Korna.

\section{Kotryna Rekašiūtè}

\section{SOME ASPECTS OF THE MASONIC RELATIONS OF MARTIN LUDWIG RHESA'S AND HIS LITHUANIAN ACTIVITIES}

\section{Summary}

Since the eighteenth century, it would be useful to draw attention to the so-called Freemasonry movement which has intensified and expanded in Europe at that time. Characterized by the freedom of thought and culture, as well as the abundance of ideas, the Age of Enlightenment influenced the mentality of the educated intellectuals in the eighteenth-ninetheenth centuries. Therefore, it is only natural that quite a large number of participants in the Lithuanian cultural and other activities were members of different Masonic organizations. 
All the activities of the lodges of the East Prussia were based on the dissemination of educational ideas and the pursuit of exellence. By promoting the moral development of people, Masons regarded education as one of their main goals. The most famous and the oldest Masonic lodge of Königsberg was Zu den drei Krönen. Of course, until 1806 about 1520 members belonged to the East Prussia Masonic lodges. Professors were especially involved in Freemasonry activities. Among them was a wellknown representative of the Lithuanian culture in Lithuania, Professor of the University of Königsberg, writer and cultural figure - Martynas Liudvikas Rèza. Rèza belonged to the Masonic movement for 35 years. Carefully going into the professors' Lithuanian activities, the aspect of Rėza's Masonry is important. Lecturers and Professors from the University of Königsberg who have probably influenced Rėza (Johann Ernst Schultz, Christian Jakob Kraus, Imannuel Kant), belonged to the Masonic Society or were closely associated with it. Masonic echoes are found in Rèza's publishing activities, correspondence and in relationships with well-known scholars and writers (Johann Gottfried Jordan, Georg Friedrich Hartung, Johann Georg Scheffner and others). Probably the membership of the Society encouraged Rèza's scientific interests. It also provided favorable conditions for the preparation and release of the most important Lithuanian publications. The Masonic echoes of Rèza's Lithuanian activities are also found in relations with University of Vilnius (Gottfried Ernest Groddeck, Kazimier Kontrym). Relationships established in the Masonic Society have probably helped Rèza prepared important Lithuanian publications. 